\title{
CALENDAR OF ECONOMIC EVENTS: OCTOBER-DECEMBER 1971
}

Classification scheme for calendar items

(A) INDUSTRY-including bids, mergers, commercial policy; (B) LABOUR AND PRICES-including strikes, claims, settlements; prices; (C) OVERSEAS-including policy developments overseas (Bank rate changes), strikes; (D) INTERNATIONALincluding IMF, monetary (exchange rates) and trade, EEC; (E) UNITED KINGDOM GENERAL-including domestic policy, Cmnd papers, Bank rate and other interest rate changes, EEC entry.

(B) 1 English China Clay to cut its 12,000-strong labour force by 830 .

(C) 1 Walkout by 45,000 US East Coast dockers over guaranteed income dispute closes all deep sea ports.

(A) 2 Central Electricity Generating Board decides not to join consortium to save press at River Don (see Calendar, NIER no. 58, 29 Sept. 1971).

(B) 2 Chrysler pay deal negotiations by ASTMS for 700 foremen and technical staff at Stoke and Ryton plants, Coventry, produce rises of $£ 4.50$ a week backdated to 1 July.

(C) 4 President Nixon invokes Taft-Hartley Act to deal with US West Coast dock strike: compulsory return to work for 80-day cooling-off period. Union can resume strike on 25 December.

(E) 4 National Executive Committee's rejection of EEC entry terms endorsed at Labour Party Conference $(5,073,000$ votes to $1,032,000)$.

(B) 4400 shop stewards for toolroom men in 50 motor and engineering plants in Coventry decide to continue Monday strikes.

(B) 7 About 3,000 out of 4,700 workers at Birmingham Small Arms factory, Small Heath, Birmingham, to be made redundant as part of changes to prevent collapse of company.

(D, E) 7 Bank of England prohibits additions to nonresident holdings of various British Government securities.

(E) 8 Reduction by $\frac{1}{2}$ per cent to 8 per cent of building societies' rate of interest on mortgages.

(B) 11 Dunlop to place 600 more workers (making 950 in all) on short time because of continuing low level of home sales.

(B) 12 National talks on $£ 120$ million pay claim broken off by union leaders of 260,000 miners, with threat of strike.

(A, E) 13 Acceleration of naval construction programme, totalling $\mathfrak{£} 70$ million in next three years.

(C) 13 West German Bank rate cut by $\frac{1}{2}$ per cent to $4 \frac{1}{2}$ per cent.

(C) 13 Italian Bank rate cut by $\frac{1}{2}$ per cent to $4 \frac{1}{2}$ per cent.

(E) 14 Barclays Bank overdraft and deposit rates cut by $\frac{1}{2}$ per cent.

(A) 14 Spillers to merge its flour, baking, and animal feeds interests with those of Cooperative Wholesale Society and $J$. Lyons.

(B) 14 Claim on behalf of 1,500 workers at Shell Chemicals' Carrington works includes provisions for pay increases if cost-of-living index goes up more than 5 per cent, and 40 per cent increases in event of a three-year pay pact; and guaranteed weekly pay during a strike which results from employers breaking disputes procedure pact.

(A) 15 Receiver and manager appointed for Autonomics, principal operating subsidiary of Miles Roman Computer software group.

(B) 15 Demand for $£ 8$ a week pay rise and 35-hour week, as well as fringe benefits, lodged on behalf of 5,000 workers at Chrysler's Linwood plant, Renfrewshire.
October

(D) 15 Japan agrees to limit exports to United States of man-made and woollen textiles with three-year pact restricting their annual growth rate to 5 per cent.

(A) 15 British Rail Board to raise $\$ 50$ million by Eurodollar loan.

(A) 18 Allied Breweries plans bid for Trust Houses Forte.

(B) 18 Tally clerks' one-day strike, first of threatened series in protest at 20 sackings, halts work on 46 ships in Port of London.

(D) 19 Denmark puts 10 per cent surcharge on imports.

(B) 19 7,000 Coventry toolroom workers locked out in reprisal for their Monday stoppages. In sympathy with them, 16,000 engineering workers in the area go on strike (4 Oct.).

(B) 19350,000 farm workers awarded 8-9 per cent pay increases.

(C) 21 First National City Bank of New York adopts new 'base rate' for business loans instead of fixed 'prime' rate concept.

(A) 22 Receiver and manager appointed to take over Britten-Norman, Isle of Wight manufacturers of civil aeroplanes.

(B) 22 Hospital workers' union rejects 7 per cent wage offer.

(C) 25 Canadian Bank rate cut by $\frac{1}{2}$ per cent to $4 \frac{7}{4}$ per cent.

(B) 27 11-day-old strike by 280 oil tanker drivers and fitters made official by TGWU.

(D, E) 28 Government EEC entry terms accepted by House of Commons (356 votes to 244).

(C) 28 French Bank rate cut by $\frac{1}{2}$ per cent to $6 \frac{1}{2}$ per cent.

(A) 29 Allied Breweries decides not to go ahead with proposed offer for Trust Houses Forte (see 18 Oct.).

(C, D) $29 \$ 2,914$ million Foreign Aid Bill rejected by US Senate (41 votes to 27$)$.

(B) 1 National Union of Mineworkers begins overtime ban for pay rises of up to 47 per cent (see 12 Oct.).

(B) 1 Heathrow disrupted due to dispute over ground handling operations.

(B) 1 Rolls-Royce lays off 1,100 toolroom and related workers.

(A) 1 Birmingham Small Arms shareholders agree to rescue operations (see 7 Oct.).

(A) $2 £ 12.5$ million bid by S. Pearson and Son for Doulton and $\mathrm{Co}$.

(A, E) 3 Publication of 'Report of the Committee of Inquiry on Small Firms'. Government to set up special small firms division (Cmnd 4811).

(C) 4 Many United States banks cut prime rate by per cent.

(B) 4 Coventry toolroom shop stewards for 7,000 engineers decide by five to one vote to recommend full strike (see 19 Oct.). 


\section{November}

(B) 5 Port of London Authority announces proposals to raise charges to port users so as to increase gross revenue by 5 per cent from 1 January, and by further 5 per cent from 1 July 1972.

(C, D) 5 Soviet Union agrees to buy more than $\$ 100$ million worth of United States feed grains.

(B) 660,000 manual workers with Gas Council lodge pay claim.

(A) 8 Redland proposes to take over Purle Brothers, valued at $£ 15.25$ million.

(B) 9 British Steel Corporation plans to raise steel prices by $5-10$ per cent.

(C) 10 US Federal Reserve discount rate cut by $\frac{1}{4}$ per cent to $4 \frac{3}{4}$ per cent.

(C, D) 10 US Senate passes interim Foreign Aid Bill providing $\$ 1,144$ million for loans, technical assistance (see 29 Oct.).

(C) 11 US Price Commission issues guidelines tying further price rises to cost increases and setting ceilings on companies' pre-tax profit margins.

(A, E) 12 Government frees Horserace Totalisator Board to compete on 'equal terms' with bookmakers.

(A) 12 Contract with Govan Shipbuilders for four 26,000-ton bulk carriers for Irish Shipping confirmed.

(B) 12590 jobs to be lost through closure of William Moorhouse (Cadbury-Schweppes) jam factory in Beeston, Leeds in March 1972.

(B) 16 Executive of Amalgamated Union of Engineering Workers votes five to one in favour of Coventry toolroom strike (see 4 Nov.).

(A) 17 Ready Mixed Concrete bids $f 74$ million for Redland.

(B) 17 British Aluminium to cut its labour force by nearly 10 per cent (1,000 men) over next eight months.

(E) 18 Universities to get extra f13.1 million grant in current year to compensate for rise in cost of living.

(D) 19 North Atlantic air fares to be cut by up to 26 per cent from 1 April 1972.

(B) 19 Bread prices to be raised by Allied Bakeries by $\frac{1}{2}$ p per loaf from 6 December.

(A) 20 Birmingham Small Arms to raise $£ 3$ million by sale of most of its metal components division.

(A) 21 Sears Holdings bids $£ 20$ million for William Hill Organisation.

(B) 21 Basis agreed for settling official strike by more than 6,000 Coventry and district toolroom workers (see 16 Nov.).

(E) 21 Government to spend extra $£ 118$ million over next four years on health services, mainly for elderly and mentally ill.

(E) 22 'Report of the Commons Civil List Committee on Royal Finances' (House of Commons Paper no. 29).

(A, E) 22 Government announces another $f 185$ million public expenditure over next two years, mainly by nationalised industries.

(A) 23 Allied Breweries bids $£ 132$ million for Trust Houses Forte.

(A) 23 William Hill Organisation rejects as inadequate $£ 20$ million bid by Sears Holdings (see 21 Nov.).

(E) 24 Government to tighten enforcement of regulations governing charter travel by air.

(A) 24 Richard Costain and Hanson Trust plan merger through new holding company.

(E) 25 White Paper 'Public Expenditure to 1975-76', provides for increases in public expenditure totalling $£ 482$ million in current year and $£ 718$ million in 1972-73 (Cmnd 4829).

\section{November}

(E) 25 All big London banks announce cuts of per cent in lending rates (following Barclays on 14 Oct.).

(C) 26 Taft-Hartley Act invoked against US East Coast dock strikers.

(A) 27 Barclay Securities to buy major part of Lines Bros in deal worth $£ 5.28$ million (see Calendar, NIER no. 58, 7 and 29 Sept.).

(E) 27 Three of the four big banks (Lloyds, Midland, and National Westminster) set up joint company to launch planned credit card.

(B) 30 Union leaders of nearly 1 million local government manual workers agree to $£ 19$ a week minimum earnings guarantee (increasing basic rates by 7.4-7.8 per cent) and introduction of $£ 1$ a week 'lead-in' payment for productivity deals.

December

(B) 1 Major provisions in Industrial Relations Act covering collective bargaining and union recognition implemented.

(B, E) 1 Government accepts all recommendations of 'Review Body on Doctors' and Dentists' Remuneration 1971' (Cmnd 4825).

(A) $2 £ 290$ million bid by Beecham Group for Glaxo,

(A) 3 Richard Costain and Hanson Trust drop merger plans (see 24 Nov.).

(B, E) 6 'Review Body on Top Salaries First Report, Ministers of the Crown and Members of Parliament', recommends 38 per cent increase in salaries of Ministers and MPs (Cmnd 4836).

(C) 7 Libyan Government nationalises British Petroleum's interests, and intends to withdraw deposits from British banks.

(A, E) 7 Government to write off up to $£ 350$ million of British Steel Corporation's debts.

(D, E) 8 Government to retain all import quotas on cotton textiles from Commonwealth Preference Area in 1972 , in addition to previously announced 15 per cent tariff.

(B) 9 Miners' union executive votes unanimously for national strike (timed for 9 January) after 58.8 per cent of members vote for it (see 1 Nov.).

(A) $9 £ 15.25$ million merger of Redland with Purle Brothers to go ahead (see 8 Nov.).

(A) 10 Takeover panel holds up posting of Allied Breweries' formal offer for Trust Houses Forte (see 23 Nov.).

(A, E) 10 Government gives assurances about future commercial success of Concorde.

(D, E) 12 Britain, Ireland, and Denmark reach agreement with Six on new Common Fisheries Regulation.

(C) 13 US Federal Reserve discount rate cut by $\frac{1}{\text { per }}$ cent to $4 \frac{1}{2}$ per cent.

(C) 13 Prime rate cut by per cent to 51 per cent by Morgan Guaranty Trust of New York and Chase Manhattan.

(D) 14 President Nixon agrees to devalue dollar against gold as part of settlement worked out with President Pompidou.

(E) 14 Government to repay all outstanding post-war credits-about 1130 million-between April and September 1972.

(B, E) 14 Government reforms of employment service to be undertaken. Employment services and payment of benefits to be separated.

(C) 15 United States deadline for repatriation of funds from companies' overseas subsidiaries extended from year-end to 29 February 1972.

(E) 16 Government to protect purchasing power of national insurance retirement pensions and related benefits by a review every year.

(A) 16 British Petroleum announces $£ 160$ million programme to develop Forties Field oil discovery in North Sea. 


\section{December}

(B) 16 Miners and electricity supply workers reject pay offers of $7 \frac{1}{2}$ and 7.2 per cent respectively.

(B) 16950 redundancies announced by C. A. Parsons, subsidiary of Reyrolle Parsons.

(C) 17 United States dockers' union rejects offer to end West Coast dispute (see 4 Oct.).

(E) 17 Local Authorities to pay more on new borrowing from Public Works Loan Board.

(B) $176 \frac{1}{2}$ per cent pay rises for police, 7.6 per cent for male hospital workers, and 8.3 per cent for female hospital workers, backdated to September 1971.

(D) 19 Group of Ten settlement : United States import surcharge and related provisions of job development credit to be lifted and immediate and substantial revaluation against dollar of all leading currencies except Canadian dollar (still floating). At later stage, US Government to recommend to Congress devaluation of dollar against gold from $\$ 35$ to $\$ 38$ per ounce in return for trade concessions by EEC, Canada, and Japan. (For complete list of currency realignments, see Chapter IV, World Economy, page 76.)

(D, E) 19 Chancellor removes special exchange control restrictions (see 31 Aug. and 7 Sept.).

(D) 20 Foreign exchange markets closed in London and most European centres.

(B) 20 Bank pay agreement between employers and Banking Staff Council, NUBE, and staff associations to give 7 per cent rise from 1 January 1972 to 165,000 clearing bank staff.
December

(B) 21 Leaders of 280,000 miners decide to go ahead with national strike from 9 January 1972, after failing to persuade Coal Board to improve $7 \frac{1}{2}$ per cent pay offer (see 9 Dec.).

(B, E) 22 Government to make grants of $£ 27$ million to British Rail Board and $\mathfrak{f} 7$ million to National Bus Company for 1972 , to enable them to keep price rises down to 5 per cent.

(C) 23 West German Bank rate cut by $\frac{1}{2}$ per cent to 4 per cent.

(C) 23 US West Coast dockers have present terms extended by Federal Mediation Service, thus putting off possible strike resumption date to 10 January (see $17 \mathrm{Dec}$.).

(B) 27 Improved pay offer of $£ 3.60$ a week rejected by representatives of 5,000 workers at Chrysler's Linwood factory with threat to strike on 10 January (see 15 Oct.).

(C) 29 Japanese Bank rate cut by $\frac{1}{2}$ per cent to $4 \frac{3}{4}$ per cent.

(C, E) 29 Britain prepares for military withdrawal from Malta, after British refusal of claim for extra $£ 4.25$ million over and above $£ 4.75$ million agreed for six-month period ending 31 March 1972.

(B) 30 Nine-week strike at Rolls-Royce aero engines plant at Bristol ends, with return to work on 3 January (see 1 Nov.). 